\title{
Research on the Employment of Graduates Majoring in Product Design in Shandong Universities
}

\author{
Hengwang Zhang \\ Shandong University of Arts, Shandong, China
}

Keywords: Product Design Major; Graduates; Problems of Employment.

Abstract: According to the specific requirements of higher education teaching reform in the new era, focusing on the actual teaching and personnel training of product design undergraduate major in local colleges and universities in Shandong Province, combining with the development advantages of local enterprises, this paper focuses on training students' employment and entrepreneurship ability of Product Design Major, perfecting the teaching mode and reforming the teaching methods of product design courses. The goal is to improve the practical ability and core professional accomplishment of the students majoring in product design. Starting from theoretical analysis, empirical research, rational research and case practice, this paper systematically studies the employment and entrepreneurship of product design graduates in local colleges and universities.

\section{Introduction}

Since entering the new era, the state and government's education departments have made clear the requirements of employment and entrepreneurship education for contemporary college graduates through a series of policy documents, and pointed out a new direction for innovation and entrepreneurship teaching for undergraduates majoring in product design in local colleges and universities [1]. This has helped to implement the strategy of innovation-driven development, and played a theoretical foundation for the training of craftsmen and compound talents of innovation and entrepreneurship.

At present, in the more developed countries such as Europe and the United States, the status of industrial industries in their national economies is constantly improving, which has played a very important role in the employment of graduates of industrial design and product design. For example, the United Kingdom is a European country that pays great attention to design. It relies on industrial design to put British industry in a leading position. In addition, Japan also attaches great importance to "industrial power". Since the 1950s, the "design and establishment" strategy has been implemented-from government support and guidance to corporate groups 'focus on design and new product development. The proportion of funds invested in design and development has reached $2.8 \%$ of the gross domestic product, ranking first in the world. Facing the rapid development of the industrial industry, foreign experts and scholars have studied the connotation of the industrial industry, the market subject, and the training model of college students. Although the research on industrial employment in developed countries such as Europe, America and Japan has already achieved results, there are relatively few studies on the impact of product employment in local 
institutions.

In contrast, there are many domestic studies in this field. For example, in the "Problems and Reflections on the Employment of Undergraduate Students in Newly Established Local Undergraduate Colleges", Xie Anguo proposed that graduates of newly established local undergraduate colleges face severe employment problems [4]. It shows that graduates are increasing year by year, the employment rate is low, the quality of employment is not high, the nature of the employment unit and the employment industry are relatively single, and it is difficult to start independent businesses, and the employment outlook is biased. In the article "Research and Practice on the Reform of the Curriculum System of Industrial Design Specialty Oriented by Employment", Zhu Yanqin put forward that the level of industrial design education and the quality of designers are still far from meeting the needs of the rapid economic development of the country [5]. Although there are many views on the employment of graduates from relevant local undergraduate colleges, the current research focuses on theoretical aspects, and the depth of research is not enough. There is very little empirical research and there is a lot of research space.

Through extensive collection and integration of domestic and foreign literature and academic achievements on the study of employment and entrepreneurship of graduates from local colleges and universities, the teaching and talent training mode of Product Design Specialty, the author excavates the essence of employment and entrepreneurship of graduates and the latest policy requirements, and refers to the experience of apprenticeship, dual system and cooperative education abroad, as well as draws on the views and opinions of Chinese experts and scholars on the employment and entrepreneurship of product design graduates in local colleges and universities, to analyze the academic innovation value of the employment and entrepreneurship of product design graduates in local colleges and universities.

\section{Research Methodologies}

Taking several local colleges and universities in Shandong Province as an example, the author collects the opinions and suggestions of product design teachers and graduates, consults with authoritative experts and scholars of employment and entrepreneurship education at home and abroad, and takes product design teachers and students of our school and neighboring brother colleges as research objects. On the one hand, from the perspective of teachers, this paper analyzes the actual impact and practical role of higher education reform in the new era on the employment and entrepreneurship of product design graduates, and understands the ways and means adopted by local colleges and universities in guiding product design graduates to carry out practical education of employment and entrepreneurship. On the other hand, from the perspective of students, this paper analyzes the new situation, opportunities and challenges faced by product design graduates in the new era, and grasps the employment level, entrepreneurship level and mentality of employment and entrepreneurship of product design graduates, so as to find out the employment and entrepreneurship problems of product design graduates in local colleges and universities in Shandong Province in the new era. Through practical investigation, the author found that local colleges and universities generally do not attach enough importance to graduates' employment and entrepreneurship, lack of publicity and implementation of the latest policy documents, and lack of employment and entrepreneurship guidance for product design theory and practice teaching.

This paper focuses on Shandong Industrial Parks, key enterprises and so on to carry out on-the-spot investigation, to analyze the development status of Shandong product design industry, study the status, categories and abilities, etc, of talents required by Product Design Major, and finally find out the fit point between the training and supply of market product design professionals and the actual demand of product design industry professionals. For example, we should adjust the 
specific content of employment and entrepreneurship education of Product Design Major around the ability and quality requirements of market to product design professionals, so as to achieve the balance between supply and demand of market product design professionals. Summing up the results of this survey, the author found that local colleges and universities have made rich achievements in deepening education supply-side reform and employment entrepreneurship teaching. At the same time, there are also some problems, such as inadequate publicity and implementation of the concept of employment entrepreneurship education concept, unscientific curriculum of employment entrepreneurship, limited level of teachers in employment entrepreneurship education, and enthusiasm of students to participate in product design innovation and entrepreneurship education is not high.

\section{Results and Main Findings}

Through empirical research, it is not difficult to find that the effect of employment and entrepreneurship of product design graduates in Shandong local colleges and universities is not ideal [2]. Although some local colleges and universities have realized the important value of employment and entrepreneurship education, they have also carried out to some extent on product design professional practice training, innovation and entrepreneurship education practice. However, it has not achieved relatively optimistic results, especially in the process of career planning, employment and entrepreneurship, product design graduates still face many difficulties, such as not keeping up with the call of the state, the needs of the times and other scientific and reasonable positioning of career orientation, not combining with the market demand for product design talents to optimize practical teaching and innovation entrepreneurship teaching content, not actively exercising and scientifically promoting self-professional practice ability, practical ability, application ability, etc, leading to the existence of demand for market product design professionals and the supply of product design professionals in local colleges and universities.

The disjointed situation has seriously affected the quality of employment and entrepreneurship of product design graduates, and is not conducive to the implementation and application of innovation-driven development strategy and Made-in-China 2025 strategy [3]. Therefore, for local colleges and universities, it is necessary to start with professional teaching, personnel training, school-enterprise cooperation and integration of production and education, to explore the teaching system of Product Design Major that meets the needs of market product design professionals, combine dynamic with static, and explore course system and core course standards of Product Design Major based on job process orientation. Taking the typical work tasks in product design enterprises as clues to determine the course settings, gradually realizing the role transformation of students from learners to workers; innovating professional teaching activities and organizing teaching contents with typical product design as the carrier, cultivating the core competence of product design students, so as to adapt to the actual development needs of market occupational posts.

\section{Conclusion}

This research specifically analyzes the opportunities and challenges faced by graduates of Product Design Major in Shandong Province in employment and entrepreneurship mainly through the ways of literature analysis, practice research, policy interpretation, case study, practical application and so on, and on this basis, combs and integrates the problems of product design undergraduates in local colleges and universities in employment and entrepreneurship, and finally draws the practical countermeasures of employment and entrepreneurship.

First, local colleges and universities should actively propagate the concept of employment and 
entrepreneurship education, innovate the thinking of entrepreneurship education, improve the knowledge of product design teachers and students about employment and entrepreneurship education, update the teaching content of employment and entrepreneurship course, form a standardized employment and entrepreneurship model, rationally plan their career, and focus on guiding product design students to become the reserve force of the market product design industry. Second, should actively investigate and analyze the specific requirements of the market for product design professionals and innovative entrepreneurs, so as to timely adjust the teaching content and mode of employment entrepreneurship education in local colleges and universities, optimize the training program of product design professionals, and effectively improve product design students' theoretical level, practical ability and professional accomplishment under the guidance of 'mass entrepreneurship and innovation among all people', so as to promote students' innovation and entrepreneurship. Third, should increase exchanges and cooperation between local colleges and enterprises outside the school, establish a training base for product design talents inside and outside the school and an education base for innovation and entrepreneurship, exercise and improve the employment level and professional ability of product design graduates, strengthen their entrepreneurial thinking and ideas, and cultivate their ingenuity. Finally, should be based on the local and have national orientation, through the leading role of local colleges and universities to explore and innovate, to serve for the development of local industrial industries, promote the national product design industry reform and train the compound talents.

Secondly, local colleges and universities should make rational use of online and offline education and teaching resources to carry out employment and entrepreneurship education activities. It is inevitable that there will be product design needs in college education and teaching and community activities, such as uniform design, community icon design, activity product design, creative product design, etc. Local colleges and universities can completely develop the enthusiasm and initiative of the students majoring in product design, to design products according to the characteristics of campus culture and local industry. The students should be encouraged to integrate local characteristics into product design, relying on rich economic, human and cultural resources of universities to promote sustainable development of employment and entrepreneurship model of product design graduates. They should also establish and improve the guarantee system of employment and entrepreneurship education, perfect the employment and entrepreneurship mechanism, and require excellent and entrepreneurs of Product Design Major to provide guidance and consultation for students' employment and entrepreneurship. At the same time, they should refer to the opinions and suggestions of authoritative experts and scholars, one-to-one follow-up and guide product design students to engage in employment and entrepreneurship activities, should introduce high-quality employment and entrepreneurship mentors, promote product design professional teachers to infiltrate innovative entrepreneurship ideas in the teaching process, guide students to plan their careers rationally, change traditional employment and entrepreneurship ideas, and actively create a good atmosphere for employment and entrepreneurship.

In addition, local colleges and universities can also timely adjust the teaching content and employment entrepreneurship education mode of Product Design Major in the light of market data feedback and statistics of graduates' employment and entrepreneurship, so as to better adapt to the requirements of the new era market for the ability and accomplishment of product design talents, inject more life into the innovation and development of product design industry, and contribute more to the modernization of the country and society.

\section{References}

[1] Liu Yu. Improving the Effectiveness of College Employment and Entrepreneurship Guidance 
Services from the Perspective of Supply-side Reform [J]. Shanxi Agricultural Economy, 2017 (20). (In Chinese)

[2] Yang Zhiyu, Yanbian Prefecture: Promoting the Service Level of Employment and Entrepreneurship for College Graduates [J]. Labor Security World, 2017 (22). (In Chinese)

[3] Zhao Yangang, Wang Zhichen. Research on Improving the Effectiveness of College Employment and Entrepreneurship Guidance Services from the Perspective of Supply-side Reform [J]. Guangxi Social Sciences, 2016 (09). (In Chinese)

[4] Xie Anguo. Problems and Reflections on the Employment of Undergraduate Students in Newly Established Local Undergraduate Colleges [J]. Continue Education Research, 2017 (02). (In Chinese)

[5] Zhu Yanqin. Research and Practice on the Reform of the Curriculum System of Industrial Design Specialty Oriented by Employment [J]. Journal of Jiangsu Teachers University of Technology, 2013, 19(1): 93-96. (In Chinese) 